\title{
Exigibilidad de la cláusula penal en época de crisis sanitaria(*)
}

\section{Enforceability of the penal clause during a health crisis}

\author{
Olga Alejandra Alcántara Francia ${ }^{(*)}$ \\ Universidad de Lima (Lima, Perú)
}

\begin{abstract}
Resumen: El presente artículo plantea una reflexión sobre el devenir de la cláusula penal, sus funciones, su utilidad y su vigencia. Con ayuda de los métodos descriptivo, hermenéutico-jurídico y comparado, realizamos una revisión de la normativa nacional y extranjera, acerca de la intangibilidad del contrato, la facultad moderadora de los jueces y la intervención legislativa en la reducción de la cláusula penal, como medida temporal como consecuencia de la crisis sanitaria.
\end{abstract}

Palabras Clave: Cláusula penal - Contrato de arrendamiento - Función punitiva - Pena cumulativa - Derecho Civil

\begin{abstract}
This article presents a reflection on the future of the penal clause, its functions, its usefulness and its validity. With the help of descriptive, hermeneutic-legal and comparative methods, we carry out a review of national and foreign regulations, about the intangibility of the contract, the moderating power of the judges and the legislative intervention in the reduction of the penal clause, as a measure temporary as a result of the health crisis.
\end{abstract}

Keywords: Contractual penalty - Lease - Punitive function - Cumulative penalty Private Law

$\left(^{*}\right) \quad$ Nota del Editor: Este artículo fue recibido el 23 de agosto de 2020 y su publicación fue aprobada el 7 de octubre.

$\left({ }^{* *}\right)$ Abogada. Profesora de la Facultad de Derecho de la Universidad de Lima. Candidata a Doctora en Derecho por la Universidad Carlos III de Madrid, España. Master en Derecho con especialidad en Derecho Europeo por la Universidad Católica de Lovaina (Bélgica), Máster en Economía y Derecho de Consumo por la Universidad de Castilla-La Mancha (España), Máster en Derecho Empresarial por la Universidad de Lima. ORCID: https://orcid.org/0000-0001-9159-1245. Correo electrónico: oalcanta@ulima.edu.pe 


\section{Introducción}

Se vive un periodo teñido por la pandemia causada por una enfermedad de contagio masivo que ha sumido a los gobiernos del mundo entero en una crisis sanitaria inimaginable. El impacto económico de esta crisis ha afectado, sobre todo, a aquellas sociedades con debilidades institucionales y fragmentadas a nivel social. La paralización de muchas empresas ha traído consigo el desempleo y, por consiguiente, la imposibilidad para muchas personas de seguir ejecutando sus obligaciones contractuales.

La cláusula penal recobra importancia en esta época debido, justamente, a las dificultades que los deudores enfrentan para cumplir con sus respectivas prestaciones, más aún, si éstas son respaldadas por penalidades. El debate relativo a la mutabilidad o inmutabilidad de la cláusula penal y su revisión judicial, no está agotado, así como tampoco la discusión sobre las funciones de la cláusula penal.

Los contratos de arrendamiento son por mucho los que se han visto más afectados en este contexto. Tanto los arrendatarios de casas-habitación como de establecimientos comerciales se han visto en serias dificultades para poder cumplir con sus obligaciones. Los arrendadores, por su parte, enfrentan también los estragos de las rentas impagas durante cuatro o cinco meses y de las penalidades exigibles pero imposibles de cumplir.

En esta coyuntura, la intervención judicial moderadora de la cláusula penal cobra relevancia, pues se presenta como un remedio ante la eventual desproporción o exceso que ésta pudiera presentar.

El presente trabajo constituye una reflexión acerca de la problemática vinculada a la exigencia de las penalidades en el marco de los contratos de arrendamiento, la solución ofrecida por la legislación civil nacional y extranjera, y, sobre la propuesta de modificación del artículo 1346 del Anteproyecto de Reforma del Código Civil peruano. Además de los métodos hermenéutico-jurídico y descriptivo, para el tratamiento de la bibliografía especializada se ha utilizado el método comparado.

El ensayo está formado por cuatro partes: las dos primeras, se ocupan de la revisión bibliográfica de los orígenes, modalidades y funciones de la cláusula penal; la tercera, se centra en la moderación de la |cláusula penal y, la cuarta, se centra en el análisis de la inmutabilidad la cláusula penal.

\section{Generalidades}

El Derecho peruano, así como la mayoría de legislaciones civiles de la región, está fuertemente influenciado por el derecho francés. El Derecho Civil peruano, como tantos otros, es heredero del Code Napoleónico de 1804, obra magistral que ha marcado la tradición civilista peruana desde la aparición de nuestro Código Civil de 1852.

El Code se ocupa de la cláusula penal en la Section VI Des obligations avec clauses pénales, Chapitre IV Des diverses espèces d'obligations, Titre III Des contrats ou des obligations conventionnelles en général, Livre troisième - des différentes manières dont on acquiert la propriété, específicamente en los artículos 1226 al 1233 antes de que entrara en vigor la Reforma al Libro de Obligaciones el 1 de Octubre de 2016. A partir de esa fecha, el artículo $1231-5^{(1)}$ sintetiza en un solo texto las disposiciones citadas relativas a la cláusula penal.

La cláusula penal en el Derecho francés ha sido diseñada para servir de garantía de cumplimiento de una obligación principal (art. 1231-5, Code). Se trata, entonces, de un pacto de naturaleza accesoria, pactada generalmente en dinero, establecida para aquellos casos en los que el deudor no cumpla con sus obligaciones, o lo haga de manera parcial, tardía o defectuosa. Es posible acordarla también para indemnizar los perjuicios moratorios (Prado, 2019). Este pacto accesorio recibe también otros nombres, como multa convencional o pena convencional (Acedo Penco, 2011).

El Derecho español que también ha influenciado notablemente a nuestros legisladores no ha establecido una definición legal de cláusula penal, ya que el Código Civil no ofrece un concepto de cláusula penal en ninguno de los cuatro preceptos que le dedica (arts. 1152-1155 CC). Tampoco lo hace el Código de Comercio en el único artículo en que la regula (art. 56 Código de Comercio). Sin embargo, el concepto de cláusula penal ha sido formulado por la jurisprudencia y la doctrina. La sentencia clásica del Tribunal Supremo a la que todavía hoy remite la jurisprudencia es la STS, 1 a $^{\text {a }}$ de 8 de enero de 1945 (RJ 7), que definió la cláusula penal poniendo de relieve su doble función, liquidatoria y coercitiva (Marín, 2017).

(1) Artículo 790, Código Civil y Comercial de la Nación. "Concepto. La cláusula penal es aquella por la cual una persona, para asegurar el cumplimiento de una obligación, se sujeta a una pena o multa en caso de retardar o de no ejecutar la obligación". 
La doctrina española, por su parte, ha definido a la cláusula penal, como una obligación accesoria (Roca \& Puig, 1948, p. 269) a cargo del deudor que, en caso de incumplimiento de la obligación principal (Albaladejo, 1997), deberá pagar al acreedor una prestación (generalmente) pecuniaria. Para otros autores, se trata de una sanción convencionalmente establecida para los casos de incumplimiento o cumplimiento defectuoso (Díez-Picazo, 2008) (Cabanillas, 1991). Por su parte, el profesor Carrasco Perera describe a la cláusula penal como "una determinación accesoria de un negocio jurídico, en virtud de la cual la conducta del deudor contraria a la obligación 'asegurada' comporta que se cumpla una condición suspensiva que obliga al incumplidor (...) al pago de una deuda de dinero u otro sacrificio pre estipulados a favor del acreedor" (Carrasco, 2013). De forma mayoritaria, se decanta por considerar a la cláusula penal como una sanción contractual (Arana de la Fuente, 2009) (Blanco, 1996) impuesta por el perjuicio causado por el incumplimiento de la obligación.

En Latinoamérica, el Derecho argentino a través del Código Civil y Comercial de la Nación de 2015, recoge en los artículos 790 a 804 las disposiciones normativas sobre cláusula penal y sus efectos. En opinión de Jalil (2016), el precepto que define a la cláusula penal (artículo 790 )(2) es más preciso y concreto que el anterior, poniendo en evidencia las finalidades resarcitoria y compulsiva de la cláusula penal. En cuanto a su objeto, la cláusula penal recaer en el pago de una suma de dinero, o cualquiera otra prestación que pueda ser objeto de las obligaciones, bien sea en beneficio del acreedor o de un tercero (artículo 791). Es importante señalar, que la cláusula penal resulta exigible si el incumplimiento no se debe a una causa ajena o externa a la relación contractual, liberando al deudor, como la fuerza mayor o el caso fortuito.

En el Derecho colombiano, el artículo 1592 del Código Civil,establece que la cláusula penal es aquella en la "que una persona, para asegurar el cumplimiento de una obligación, se sujeta a una pena que consiste en dar o hacer algo en caso de no ejecutar o retardar la obligación principal". En un pronunciamiento de la Corte Suprema de Justicia, se señala que "la cláusula facilita el cobro de los perjuicios derivados del incumplimiento de la obligación garantizada" (...) "que implica una liquidación de los perjuicios por la no ejecución o el retardo de la obligación principal, realizada directamente por las partes, de manera anticipada y con un "carácter estimativo y aproximado", que en principio debe considerarse "equitativo" (...)"fijada por los contratantes, de ordinario con la intención de indemnizar al acreedor por el incumplimiento o por el cumplimiento defectuoso de una obligación, por norma general se le aprecia a dicha prestación como compensatoria de los daños y perjuicios que sufre el contratante cumplido, los cuales, en virtud de la convención celebrada previamente entre las partes, no tienen que ser objeto de prueba dentro del juicio respectivo" (Contreras, 2012).

En el Derecho peruano, de forma similar al Derecho español, no se cuenta con una definición legal de cláusula penal en el Código Civil. Sin embargo, en la Exposición de Motivos del Código Civil peruano de 1984 se señala que: "La cláusula penal, legislada en los artículos 1341 a 1350 , se concibe como una relación obligacional destinada a que las partes fijen la reparación para el caso de incumplimiento". En esta serie de artículos se recogen los diferentes tipos de cláusula penal: compensatoria, moratoria, divisible, indivisible y solidaria (sobre los que volveremos, más adelante) poniéndose énfasis en sus funciones y efectos.

Del lado de la doctrina peruana, los destacados civilistas, Osterling \& Castillo, han definido a la cláusula penal como la "estipulación en un contrato que se refiere a la pena o penalidad convenida para el caso de incumplimiento (...) independientemente de si dicha cláusula sólo alude a tal penalidad o si incluye, además, disposiciones de otra naturaleza" (Osterling \& Castillo, 2008, p. 939). Para el profesor Cárdenas Quirós, se trata de un "(...) mecanismo compulsivo derivado de una relación obligatoria constituido por una prestación de dar, hacer o no hacer que el deudor (...) se obliga a ejecutar (...) en el supuesto de inejecución total o de cumplimiento parcial, tardío o defectuoso de la obligación principal" (Cárdenas, 1994, p. 349).

De las definiciones propuestas por la doctrina peruana se puede extraer lo siguiente:

- La cláusula penal es un instrumento jurídico con fines coercitivos.

- La cláusula penal involucra el establecimiento de una penalidad, pero también puede incluir disposiciones de otra naturaleza.

(2) Artículo 790, Código Civil y Comercial de la Nación. “Concepto. La cláusula penal es aquella por la cual una persona, para asegurar el cumplimiento de una obligación, se sujeta a una pena o multa en caso de retardar o de no ejecutar la obligación". 
Esto nos lleva ocuparnos de las funciones de la cláusula penal identificadas por la doctrina peruana e internacional (independientemente, de la modalidad adoptada). Como bien, señala Marín (2017), la cláusula penal cumple una función genérica de garantía. No obstante, como bien señala el autor citado, esta función de garantía no es equiparable a la función desempeñada por otros institutos jurídicos como la fianza, el aval o incluso la solidaridad pasiva. La cláusula penal no es asimilable a las garantías personales, porque no asegura el cumplimiento del contrato, sino más bien, el resarcimiento de los daños que dicho incumplimiento puede ocasionar. Sin embargo, la incorporación de una cláusula penal puede promover el cumplimiento del deudor, pero no otorga al acreedor la seguridad acerca de la satisfacción de su interés. Esto último, justamente, constituye la causa de las garantías personales.

La cláusula penal cumple también una función sustitutiva o liquidatoria. La jurisprudencia española, interpretando el artículo 1152, primer párrafo del CC, señala que la función natural y esencial de la cláusula penal es la liquidación de los daños y perjuicios producidos o derivados del incumplimiento de la obligación principal (o de su cumplimiento defectuoso) (STS, $1 .^{a}$ de 17 de noviembre de 2004; RJ 7239, MP: José Ramón Ferrándiz Gabriel, FD 6.), sustituyendo a la indemnización sin necesidad de aportar prueba sobre los daños y perjuicios ocasionados (STS, 1 a $^{\text {a }}$ de 28 de septiembre de2006 ; RJ 6390, MP: Ignacio Sierra Gil de la Cuesta, FD 2.).

De lo afirmado por la doctrina jurisprudencial española y de lo previsto en el Código Civil español, la ejecución de la cláusula penal viene a sustituir la indemnización por daños y perjuicios, aún cuando éstos sean superiores o inferiores a los realmente sufridos o existentes, e incluso aún cuando el incumplimiento no haya ocasionado daño o perjuicio alguno. De ocurrir así, hay que entender que la aplicación de la cláusula penal excluye la exigencia del cumplimiento forzoso por parte del acreedor, salvo si el contrato incluye ambas posibilidades (artículo 1153, CC español) ${ }^{(3)}$.

La doctrina latinoamericana atribuye a la cláusula penal una función indemnizatoria o resarcitoria. Se ha señalado que esta figura jurídica "(...) está destinada exclusivamente a limitar el resarcimiento de los daños que pueden originarse en el incumplimiento de la obligación" (Kemelmajer de Carlucci, 1981, p. 3); sin embargo, consideramos que la cláusula penal no tiene por finalidad el resarcimiento o indemnización de daños, pues procede su ejecución aún cuando el acreedor no hubiera, necesariamente, padecido daños por incumplimiento. Por ello nos parece más adecuado afirmar una función de sustitución (de la penalidad por la indemnización) o de una liquidación anticipada de daños (que podrían o no ocasionarse debido al incumplimiento).

El Código Civil peruano no se pronuncia expresamente acerca de la exclusión de la exigencia del cumplimiento forzoso de la obligación incumplida, en caso, el acreedor opte por el cobro de la penalidad. Sin embargo, hay que entender que es así, y que resulta de la propia naturaleza de la cláusula penal "el que ésta no pueda acumularse a la prestación in natura" (Osterling \& Castillo, 2008). Salvo, como veremos más adelante, de lo previsto por el artículo 1342 CC.

Respecto de la función coercitiva, punitoria o compulsiva, se ha señalado que la "fuerza coercitiva" se expresa en la agravación del resarcimiento a fin de conminar al deudor al cumplimiento de sus obligaciones (Marín, 2017). La función punitoria resulta de la naturaleza misma de la cláusula penal, pues, en tanto pena privada, la vocación sancionadora estaría ínsita. Para el autor citado, la "función coercitiva de la cláusula penal queda especialmente patente en la pena cumulativa, aquélla que permite al acreedor exigir conjuntamente el pago de la pena y el cumplimiento de la obligación principal (...)" (p. 86).

La jurisprudencia española reconoce a la cláusula penal, la función de coerción, sanción o punición ${ }^{(4)}$; no obstante, esta no

(3) Código civil español, artículo 1153: "Tampoco el acreedor podrá exigir conjuntamente el cumplimiento de la obligación y la satisfacción de la pena, sin que esta facultad le haya sido claramente otorgada".

(4) La Sentencia del Tribunal Supremo 530/2016, de 13 de Septiembre, afirma que: "No cabe duda de que, como regla, y salvo en condiciones generales de la contratación entre empresarios y consumidores o usuarios (art. 85.6 de la Ley General para la Defensa de los Consumidores y Usuarios), nuestro Derecho permite las cláusulas penales con función coercitiva, sancionadora o punitiva: no sólo de liquidación anticipada de los daños y perjuicios que puedan causar los incumplimientos contractuales por ellas contemplados". Y también, la Sentencia del Tribunal Supremo 126/2017, de 24 de Febrero analiza la siguiente cláusula penal: "En la estipulación novena del contrato se pactó una expresa cláusula penal para el caso de incumplimiento contractual, consistente en el pago igual al producto de multiplicar la recaudación media mensual habida desde el momento en que entró en vigor el contrato hasta el momento en que se produce el incumplimiento del mismo, por el número de meses que queden pendientes hasta el vencimiento del plazo contractual pactado". 
es una posición unánime. Así, encontramos que la doctrina y jurisprudencia belga han descartado se oponen a reconocer una función conminatoria a la cláusula penal. Biquet-Mathieu (2004), indica que a pesar de su denominación, la cláusula penal, no está orientada a castigar o punir en aquellos supuestos, en los que, su efecto disuasivo hubiera fracasado (Wéry, 2001, p. 249). La única función que las partes pueden asignarle es de naturaleza indemnizatoria, cayendo en la paradoja señalada por Moreau-Margreve (2000, p. 249): "la clause pénale ne peut pas être pénale" (la cláusula penal no puede ser penal). La cláusula penal no se dirige a reparar un daño potencial. Esta es la solución adoptada por la jurisprudencia del Tribunal de Casación consagrada en el Código Civil belga a través de a una Ley de 23 de Noviembre de 1998. La Exposición de Motivos de esta norma deja claramente establecida la función indemnizadora de la cláusula penal y el rechazo a su consideración como pena privada ( $\mathrm{y}$, en consecuencia, la admisión de una función punitiva) (Lano, pp. 14 - 15).

Sin embargo, un sector de la doctrina, considera que la cláusula penal sí cumple una función compulsiva. En nuestra región citamos a Borda, quien remarca la función de "(...) compulsar a los deudores a cumplir con sus obligaciones, ante la amenaza de una sanción por lo común más gravosa (...)"; en el Derecho belga, otros estudiosos como Van Ommeslaghe (Van Ommeslaghe, 1986) o Moreau-Margreve (MoreauMargreve, 2000), son favorables a la admisión de la función compulsivo-punitiva de la cláusula penal.

Afirmar que la cláusula penal cumple una función resarcitoria resulta contradictorio frente al hecho de que no siempre un incumplimiento genera daños al acreedor; y ello no impide al acreedor exigir el pago de la cláusula penal. O incluso siendo los daños ocasionados mínimos en comparación con la penalidad establecida, no inhibe el derecho del acreedor de cobrarla. Por ello, coincidimos con el profesor Soto (2016) cuando señala que la cláusula penal no cumple una función indemnizatoria o resarcitoria; sino más bien punitiva o sancionadora.

Otra de las funciones de la cláusula penal, propuesta por la doctrina, es la denominada preventiva o disuasiva. Al respecto, señala Soto (2016) que la incorporación de una cláusula penal en un contrato tiene por finalidad reforzar el cumplimiento, evitando que cualquiera de las partes incurra en incumplimiento de una o más obligaciones. En otros términos, la cláusula penal tiene por finalidad desincentivar un posible incumplimiento de las obligaciones (Soto, 2016, p. 457).

\section{Modalidades de cláusula penal}

La doctrina ha identificado algunas modalidades de cláusula penal recurrentes en los contratos, éstas son:

- Cláusula penal sustitutiva o compensatoria

- Cláusula penal moratoria y cumulativa

- Cláusula penal penitencial

El artículo 1341, CC se refiere a la cláusula penal compensatoria señalando que "(...) tiene el efecto de limitar el resarcimiento a esta prestación y a que se devuelva la contraprestación, si la hubiere (...)". En el Derecho español, se le conoce como "pena sustitutiva o liquidatoria", porque se incluye en el contrato a fin de sustituir la indemnización resultante del incumplimiento. Esta figura presenta una ventaja para el acreedor pues no deberá probar los daños sufridos ni su cuantía, pues son reemplazados por el pago de la penalidad. A pesar del nombre de esta modalidad, consideramos que no debe equipararse la función compensatoria con la idea de indemnización o resarcimiento, pues en realidad, se trata de compensar el incumplimiento contra el pago de una penalidad. El Código Civil no alude a una indemnización de daños patrimoniales (y/o extrapatrimoniales). Sí hace referencia a una excepción: cuando se haya estipulado la indemnización del daño ulterior, el pago de la penalidad se computa como parte de los daños y perjuicios si fueran mayores.

En cuanto a la cláusula penal moratoria y cumulativa, el artículo 1342 CC, prevé la posibilidad de establecer una penalidad para "(...) el caso de mora o en seguridad de un pacto determinado (...)". Esta norma reconoce al acreedor, además, el derecho de exigir el cumplimiento de la obligación. La pena cumulativa o cúmulo de penas, proviene del Derecho Civil francés (artículo 1229 del Code) (5), el cual establece de forma excepcional la posibilidad de que, en caso de retardo de

(5) Artículo 1229, Código Civil francés: "La cláusula penal es la compensación de los daños y perjuicios que el acreedor sufre por el incumplimiento de la obligación principal. No puede demandarse al mismo tiempo lo principal y la pena, a menos que haya sido estipulada para el simple retardo". 
cumplimiento, el acreedor pueda exigir tanto el cumplimiento de la obligación principal como de la pena moratoria.

Cabe señalar, que la regla general prevista en el artículo 1228 del Code(6), reconoce al acreedor el derecho de exigir al deudor moroso la penalidad establecida o el cumplimiento de la obligación principal. Esto significa que el cúmulo de penas estaría prohibido salvo el caso de retardo en el cumplimiento. Solamente bajo esta hipótesis, resulta viable exigir uno de los remedios contractuales (ejecución forzosa) y, a la vez, la pena moratoria (cuya finalidad es indemnizar por el retardo en el cumplimiento).

Se excluye la posibilidad de que el acreedor pueda exigir el cumplimiento de la obligación y la reparación por equivalente establecida en una cláusula penal de tipo compensatorio, pues esto implicaría un doble pago de la misma obligación. Sin embargo, esta prohibición no recae sobre la cláusula penal moratoria.

No obstante, lo indicado, hallamos en el Derecho Civil español un tipo de cláusula penal denominada "cumulativa", la cual, dadas sus características no impide al acreedor exigir la ejecución in natura, al mismo tiempo, que el pago de la penalidad establecida, sin distinguir si la penalidad es compensatoria o moratoria.

La pena cumulativa del Derecho Civil español es entendida como aquélla que se añade a la reparación ordinaria, hallando su fundamento legal en la última parte del artículo $1.152^{(7)} \mathrm{CC}$, que establece: (...) "si otra cosa no se hubiere pactado".

Según el autor Acedo (2011), esta norma "implica la previsión por las partes que si incumple el deudor, el acreedor podrá exigir la pena pactada, además del cumplimiento forzoso, o por equivalente pecuniario" (p. 218). Para un sector de la doctrina (Espín, 1946) (Lobato de Blas, 1974), la pena cumulativa sería distinta de la pretensión simultánea de cumplimiento y la pena del artículo 1153 CC in fine (Marín, 2017). Para otros autores (Sanz, 1994) (De Castro, 2003), independientemente de la cuestión terminológica, los contratantes pueden acordar que la penalidad se añada a la reparación ordinaria, o incluso sumarse a la exigencia del cumplimiento de la prestación debida prevista en el artículo $1153^{(8)}$. En ambos supuestos la pena es cumulativa.

Esta situación permite que "la pena cumulativa puede sumarse a remedios monetarios sustancialmente idénticos: por un lado, el cumplimiento por equivalente, incluyendo los daños y perjuicios ocasionados por la inejecución de la prestación; y, por otro lado, la reparación ordinaria, la cual comprende la indemnización sustitutoria del cumplimiento" (Marín, 2017). Esto supone que el acreedor llegue a ver satisfecho su interés por duplicado. Piénsese en el caso que se hubiera pactado el pago de una penalidad, además del cumplimiento de la prestación o del cumplimiento por equivalente pecuniario (Luna, Piñeiro, Ramos \& Rubí i Puig, 2002) o una indemnización. Claramente, se puede observar el carácter punitivo de la cláusula penal, dirigida a agravar la responsabilidad del deudor que no cumple.

Volviendo al Derecho peruano, la pena cumulativa está consagrada en el artículo 1342 CC; pero es admitida, únicamente, en dos supuestos:

- Cuando se estipula para el caso de mora.

- Cuando se establece en seguridad del cumplimiento de un pacto determinado.

En el primer caso, cuando se estipula para el caso de mora, cabe preguntarse si puede exigirse el cumplimiento de la penalidad previa constitución en mora del deudor o si ésta es automática por el solo efecto de la incorporación de la cláusula penal al contrato. Según Albaladejo (1997), en las obligaciones de dar o hacer, la pena no puede ser exigida hasta que el deudor incurra en mora, lo cual, no se produce automáticamente desde que el deudor deja de cumplir, sino cuando el acreedor requiere el cumplimiento interpelando al deudor. Esto no excluye la posibilidad de que las partes puedan acordar que "se incurra en la pena automáticamente sin necesidad de que sea exigido el cumplimiento" (Osterling \& Castillo, 2014 , p. 2732). Respecto de la cuestión de si se trata o no de un supuesto de mora automática, la respuesta la brinda el artículo

(6) Artículo 1228, Código Civil francés: "El acreedor, en lugar de demandar la pena estipulada contra el deudor que está en mora, puede perseguir el cumplimiento de la obligación principal".

(7) Artículo 1152, Código Civil español. "En las obligaciones con cláusula penal, la pena sustituirá a la indemnización de daños y el abono de intereses en caso de falta de cumplimiento, si otra cosa no se hubiere pactado. Sólo podrá hacerse efectiva la pena cuando ésta fuere exigible conforme a las disposiciones del presente Código".

(8) Artículo 1153, Código Civil español. "El deudor no podrá eximirse de cumplir la obligación pagando la pena, sino en el caso de que expresamente le hubiese sido reservado este derecho. Tampoco el acreedor podrá exigir conjuntamente el cumplimiento de la obligación y la satisfacción de la pena, sin que esta facultad le haya sido claramente otorgada". 
1333 del Código Civil. En dicho artículo se establecen las hipótesis que dan lugar a la existencia de mora automática, y la estipulación de una cláusula penal moratoria no forma parte de dicho listado. No obstante, el inciso primero de la norma citada prevé su existencia por acuerdo de partes.

Un ejemplo que calza en este supuesto, es la penalidad impuesta por el arrendador por cada día de retraso en el pago de la renta mensual. Es usual hallar cláusulas penales que obligan al deudor al pago de US\$ 5 o US\$ 10 dólares por día transcurrido de demora en el pago de la renta. Cabe señalar, que el pago de la penalidad no exime al deudor del cumplimiento de la obligación esencial: pago de la renta mensual. No olvidemos que, la cláusula penal sirve para "acrecentar la responsabilidad del deudor si éste no cumple íntegra y oportunamente la obligación principal" (López, 1978, p. 69) (Cabanillas, 1991) (Lacruz, 2011).

El segundo supuesto contenido en el artículo 1342 CC (segundo párrafo), versa sobre la incorporación de una cláusula penal en seguridad del cumplimiento de un pacto determinado. Cabría preguntarse qué debemos entender por "pacto determinado". Es decir, ¿se trata de una obligación específica distinta de la obligación principal sin dejar de ser esencial? o ¿puede recaer también sobre una obligación accesoria?

Por ejemplo, si nos situamos en el marco de un contrato de arrendamiento, la obligación principal del deudor (objeto del contrato) es el pago de la renta mensual, la cual, podría venir acompañada de una cláusula penal para el caso de mora. Sin embargo, cuando el CC se refiere a un "pacto determinado" en el contexto del artículo 1342, tendríamos que remitirnos a una obligación distinta de aquella constitutiva del objeto del contrato. Eso nos llevaría a pensar, por ejemplo, en la obligación del deudor de devolver el bien una vez vencido el contrato (si no hay renovación). El arrendador (de común acuerdo con el arrendatario) puede estipular una cláusula penal que obligue al deudor a pagar US\$10 dólares por cada día transcurrido hasta el momento de entrega efectiva del bien.

En ambos supuestos es posible acumular el pago de la penalidad establecida (generalmente, en importes dinerarios) y el derecho de exigir el cumplimiento de la obligación "asegurada" por la cláusula. A diferencia de lo previsto por el legislador español, la pena "cumulativa" solamente puede ser de naturaleza moratoria y no compensatoria. El legislador peruano no contempla la posibilidad del "cúmulo" de derechos en el caso de la claúsula penal compensatoria, pues iría en contra de lo previsto por el artículo 1954 CC. ${ }^{(9)}$

Ahora bien, cabe precisar que la posibilidad de establecer una pena cumulativa, en Derecho español, procede siempre que las partes así lo hayan pactado. Pues si no se ha acordado otorgar esa facultad al acreedor, este último no podrá exigir el cumplimiento de la obligación y, al mismo tiempo, el pago de la penalidad.

\section{4. ¿Reducción o Moderación Judicial de la cláusula penal?}

Como sabemos, el principio de justicia contractual se aplica, no solamente en el periodo de "construcción" del contrato a través de disposiciones garantes de la libertad y autonomía de las partes en la formación del consentimiento, sino también como una suerte de mecanismo de control durante la ejecución del contrato. De ahí que todas las normas que reconocen una serie de acciones al acreedor frente a situaciones de incumplimiento estén orientadas a la búsqueda de un equilibrio entre los derechos de ambas partes (Ternera, 2007). La intervención del juez en la moderación de la cláusula penal (ya sea para incrementarla o disminuirla) cumple también ese fin, pues busca garantizar lo estipulado en el contrato y convenido por ambas partes, y por otro lado, evitar el abuso del derecho por una de ellas, sobre todo, en contexto difíciles como podría ser una crisis económica. Así lo ha entendido un tribunal provincial español en 2011, al considerar la crisis económica (el desplome del mercado inmobiliaria y las dificultades de financiación) como un caso de imposibilidad sobrevenida que justifica la moderación de la cláusula penal en vía judicial (Sentencia de la Audiencia Provincial de Córdoba, Sección 1: Ponente don Pedro Roque Villamor Montoro).

La facultad del juez de intervenir en los contratos moderando la cláusula penal está recogida en los más importantes códigos europeos. En este acápite realizaremos una revisión de los Códigos francés, español y alemán sobre el tema.

El Code francés, originalmente, no contenía ninguna disposición reservando al juez la facultad de moderar la cláusula penal. No obstante, en opinión de Pothier (2007), "la pena estipulada en caso de inejecución

(9) Artículo 1954, Código Civil peruano. "Aquel que se enriquece indebidamente a expensas de otro está obligado a indemnizarlo". 
de una obligación puede ser reducida y moderada por el juez cuando le parezca excesiva” (p. 200). Para el autor, “ (...) si la pena que suple los daños y perjuicios ordinarios es reducible, cuando es excesiva, con mayor razón las penas estipuladas en caso de defecto de pago de una suma de dinero, u otra cosa que se consume por el uso (...)" (Pothier, 2007, p. 202).

Es recién, a partir de 1975, que el Derecho Civil francés admite la intervención del juez gracias a la modificación interpuesta por la Ley $75-597^{(10)}$. Posteriormente, el originario artículo 1152 sufrió múltiples modificaciones hasta llegar a la Ordonnance 2016-131, del 10 de febrero de 2016, que incorpora el artículo 1231-5 con una nueva redacción, quedando los párrafos segundo y tercero, como siguen "(...) Sin embargo, el juez puede, incluso de oficio, moderar o aumentar la penalidad convenida si fuera manifiestamente excesiva o irrisoria. Cuando el acuerdo ha sido ejecutado en parte, la penalidad convenida puede ser disminuida por el juez incluso de oficio, en proporción al interés que la ejecución parcial ha procurado al acreeedor (...)"(11)

El Código Civil español contempla también esta facultad interventora del juez. El artículo 1154, permite la modificación equitativa de la pena "cuando la obligación principal hubiera sido en parte o irregularmente cumplida por el deudor". Esto implica que la facultad moderadora del juez está sujeta a los distintos grados de cumplimiento de la obligación por parte del deudor. En otros términos, si la obligación no se cumple (o el incumplimiento es absoluto) entonces no procede la intervención del juez (STS 126/2017, de 24 de febrero) ${ }^{(12)}$.

La redacción del artículo $1154 \mathrm{CC}^{(13)}$ español ha sido criticada, pues si bien resulta que, frente al cumplimiento parcial es posible modificar la pena, cuando está prevista para el caso de mora, "la pena, en principio se aplicaría tal y como la acordaron los contratantes" (Fuenteseca, 2011, p. 98). Esta facultad reconocida al juez para "modificar" la pena, ¿debe ser entendida como una rebaja o reducción de ésta? El uso de este término por el legislador español, ha sido criticado pues pareciera que el Código Civil español se "encontrara en una fase previa en la que aún hay que ajustar la pena al cumplimiento" (Fuenteseca, 2011, p. 99); no queda claro, si ese ajuste es hacia la baja o el alza. No obstante, la doctrina ha entendido que, "en caso de cumplimiento parcial, procedería una rebaja de la pena. Y aunque la expresión modificar podría incluir asimismo un aumento de la pena, quizá habría que admitir dentro del término modificación, la rebaja de la pena" (Fuenteseca, 2011).

No obstante, como en estricto, el término "modificar" no significa "rebaja o reducción", ha provocado algunas reacciones en la doctrina. Arana de la Fuente (2009), refiriéndose a la mora, señala: cuando el incumplimiento sancionado por la pena sea el retraso (...) si el deudor incurre en dicho retraso habrá que entender, a los efectos de la aplicación de la cláusula penal, que hay incumplimiento total, por lo que no cabe su modificación ex art. 1.154 $\mathrm{CC}$. Esta regla es reiterada por la jurisprudencia (...) como eventual excepción se señalan las obligaciones de tracto sucesivo o de posible división que permitieran cumplimientos parciales aceptados por el acreedor, en las que la facultad moderadora de los tribunales podría operar (p. 1655).

En opinión de Albaladejo (1997), ni el grado de culpa del incumplidor ni la intensidad del perjuicio ocasionado deben ser tomados en cuenta para la moderación. No debe serlo la intensidad del perjuicio, porque la pena no depende del perjuicio (...) No debe ser tomado en cuenta tampoco el grado de culpa, ya que éste da lugar a responsabilidad mayor o menor, independientemente de que esté pactada una pena (p. 486).

(10) La Loi 75-597 de 9 de Julio de 1975 modificó los artículos 1142 a 1231, quedando el artículo 1152 completado con el párrafo siguiente: "Sin embargo, el juez puede moderar o aumentar la pena que hubiera sido convenida, si ella, manifiestamente, es excesiva o irrisoria. Toda estipulación contraria será reputada como no escrita" (Traducción libre).

(11) Traducción libre.

(12) La STS establece que "En la estipulación novena del contrato se pactó una expresa cláusula penal para el caso de incumplimiento contractual, consistente en el pago igual al producto de multiplicar la recaudación media mensual habida desde el momento en que entró en vigor el contrato hasta el momento en que se produce el incumplimiento del mismo, por el número de meses que queden pendientes hasta el vencimiento del plazo contractual pactado."En relación con la doble función de la cláusula penal en un contrato, y en concreto sobre la redacción señalada, dice el Tribunal Supremo que: "(...) se aprecia que la sentencia recurrida da por cumplido el supuesto de hecho al que se anudaba la cláusula penal, por lo que ésta ya no podía moderarse al amparo del artículo 1154 Código Civil. Se preveía en el contrato la resolución anticipada de la relación contractual para la aplicación de la cláusula penal y asi ha sucedido (...)"

(13) Artículo 1154, Código Civil español: "El juez modificará equitativamente la pena cuando la obligación principal hubiera sido en parte o irregularmente cumplida por el deudor". 
De otro lado, el BGB alemán presenta una redacción más clara, pues el parágrafo 343 contempla la rebaja o reducción de la pena: "(1) Si una pena ya eficaz es desproporcionadamente elevada, puede ser rebajada, a petición del deudor, mediante una sentencia. Al enjuiciar la proporcionalidad se considerará todo interés legítimo del acreedor, no sólo el interés patrimonial. Tras la satisfacción de la pena queda excluida la rebaja. (2) Lo mismo rige, salvo en los casos de los parágrafos 339 y 342 , cuando alguien promete una pena para el caso de que él haga o no haga algo".

Del tenor de la norma surgen los requisitos a observar para que proceda la reducción judicial de la cláusula penal: Primero, la pena ha de ser exigible. Segundo, la pena ha de ser desproporcionadamente elevada o exorbitante. Tercero, es precisa la petición de rebaja formulada por el deudor. Cuarto, la decisión versará sobre una rebaja a un importe adecuado. Quinto, se establecen criterios para determinar el importe adecuado. Sexto, tras el pago de la pena queda excluida la rebaja (Fuenteseca, 2011, p. 100).

Destacamos, de los párrafos precedentes, la admisión de las facultades interventoras del juez para modificar o reducir la cláusula penal. En nuestro medio, el Código Civil peruano influenciado por los Códigos Civiles europeos prevé también la reducción judicial de la cláusula penal en el artículo $1346^{(14)}$. La aplicación de esta norma procede siempre que la pena sea exigible y que la reducción haya sido solicitada por el deudor. Tal como está previsto en el BGB, el deudor adquiere protagonismo, pues no se trata de una acción de oficio sino a pedido de parte.

De otro lado, la norma permite la intervención del juez para reducir la pena, en dos supuestos:

- sea manifiestamente excesiva.

- la obligación principal se hubiese cumplido en parte o de manera irregular.

En cuanto al primer supuesto, es decir, la existencia de una pena excesiva. Notamos la influencia del Derecho alemán, al sujetar la intervención judicial a los supuestos en que la pena se exorbitante o desmesurada. Eso significa que las penas con cuantías irrisorias no serían objeto de moderación judicial. Pero, sí cabría preguntarse cuándo se considera "manifiestamente excesiva" a una cláusula penal. La Propuesta de Modernización del Código Civil español en materia de Obligaciones y Contratos, señala el siguiente contenido para el artículo 1150: "El juez modificará equitativamente las penas convencionales manifiestamente excesivas y las indemnizaciones convenidas notoriamente desproporcionadas en relación con el daño efectivamente sufrido".

Esta propuesta normativa introduce algunas novedades al Código Civil español: la modificación de la pena procede siempre que ésta sea manifiestamente excesiva y notoriamente desproporcionada. No obstante, sigue utilizando el término "modificar" y no "reducir". Y además, la referencia al "daño efectivamente sufrido" no aporta claridad al tenor legal, pues sabido es que para exigir el cumplimiento de la cláusula penal no se requiere la ocasión de un daño, sino básicamente la inejecución de la obligación asegurada por la cláusula.

El legislador peruano no se ha atrevido a incluir en el Código Civil ninguna disposición que determine cuándo una pena puede ser calificada como manifiestamente excesiva o exorbitante o desproporcionada. EI antecedente más próximo lo encontramos en la propuesta original de la Comisión Reformadora del Código Civil de 1936, cuyo artículo 1917 señalaba que "el valor de la pena impuesta no puede exceder al de la obligación principal". Como indica, Soto (2016), el "codificador de 1936, tomando en cuenta los avances de la doctrina y de la legislación de entonces, esbozó un proyecto que, en primer lugar, imponía un límite legal a las penas convencionales: la obligación principal (...)" (p. 469). Esta disposición no fue incorporada al Código Civil de 1984, por lo que, correspondería a los jueces evaluar el carácter excesivo, desproporcionado o exorbitante de la penalidad.

El segundo supuesto de reducción de la pena es cuando la obligación principal se haya cumplido en parte o de manera irregular. Cuando la norma refiere al cumplimiento en parte, debemos entender una alusión al cumplimiento parcial de la obligación. Sin embargo, la expresión "cumplimiento irregular" no resulta tan clara. No olvidemos que el artículo 1151 CC, se ocupa de las acciones del acreedor frente a situaciones de cumplimiento parcial, tardío o defectuoso; en ningún momento se alude al cumplimiento irregular. En un afán de simplificación del problema, debemos entender entender entonces, ¿que se trata de un cumplimiento defectuoso?. La doctrina peruana (Soto, 2016) (Osterling \& Castillo, 2008) ha asimilado la expresión "irregular" a "defectuoso" aún

(14) Artículo 1346, Código Civil peruano. "El juez, a solicitud del deudor, puede reducir equitativamente la pena cuando sea manifiestamente excesiva o cuando la obligación principal hubiera sido en parte o irregularmente cumplida”. 
cuando, en sentido estricto, no significan lo mismo ${ }^{(15)}$.

Para Osterling \& Castillo (2014), la modificación judicial se justifica en los casos de cumplimiento parcial o irregular (defectuoso), porque el acreedor aceptó voluntariamente un pago parcial o defectuoso, no estando obligado a ello. Si el acreedor convino con el deudor en aceptar el pago de modo distinto al estipulado, o sea en forma parcial o defectuosa, y nada se acordó sobre la cláusula penal, entonces es justo que ella sea reducida y que el juez, para efectuar tal reducción, quede autorizado a modificar la prestación sustituyéndola por dinero. En caso contrario, el acreedor se enriquecería indebidamente a expensas del deudor (p. 2836).

No estaría justificada la intervención del juez si la obligación principal fuera totalmente inejecutada, y posterior, al incumplimiento, el deudor considera excesiva la cláusula penal. En opinión de los autores citados, esto podría constituir una "intervención injustificada en los asuntos ajenos, que atenta contra la seguridad de los contratos" (Osterling \& Castillo, 2014, p. 2387).

La intervención judicial para reducir la pena es una expresión del principio de la "mutabilidad de la pena" consagrado por la mayoría de los códigos civiles europeos (BGB, Código Suizo de las Obligaciones, Código Civil francés, español, belga, italiano, etc) y también por los Códigos Civiles latinoamericanos (piénsese, en los códigos civiles brasileño, mexicano, chileno, etc). El código civil peruano adopta el sistema de inmutabilidad relativa de la cláusula penal pues permite la intervención del juez para reducirla y no para aumentarla (Osterling \& Castillo, 2014).

El profesor Soto (2016), es un implacable crítico de la postura adoptada por el Código Civil peruano, para quien, resulta ilógico que el legislador peruano permita que el deudor que ha incumplido su obligación o que habiéndola cumplido parcialmente, recurra al Poder Judicial para solicitar la reducción de la penalidad que él acordó y aceptó. En el fondo, este hecho no es otro que la revisión de los acuerdos contractuales libremente acordados, máxime en caso de haber negociado y celebrado paritariamente el contrato" (p. 466).

En opinión del autor, la premisa subyacente para esta norma vendría a ser la consideración del deudor como la parte débil o frágil en la relación contractual, lo cual, en las épocas actuales, es más un mito que una realidad. Seguir tratando al deudor como la parte débil estatuye un régimen de desigualdad frente al acreedor, más aún cuando en la realidad negocial, en mcuhas ocasiones las personas no honran su palabra, no cumplen con sus obligaciones. Esto llevaría a enfocar el problema desde otra perspectiva. En el caso del deudor que cumple parcial o defectuosamente su obligación, sin consentimiento del acreedor, éste debiera poder manifestar su rechazo exigiendo el pago íntegro de la penalidad convenida. Estos argumentos vendrían a reforzar la opinión del autor citado, en pro del reconocimiento de las funciones preventiva y punitiva de la cláusula, como principales (Soto, 2016, pp. 474-476).

\section{La "inmutabilidad" de la cláusula penal en tiempos de pandemia}

En los acápites anteriores nos hemos ocupado del estudio de la cláusula penal: sus orígenes, su consagración legislativa en diferentes ordenamientos jurídicos, sus funciones, su tipología y la facultad del juez de reducirla en supuestos concretos. Nos corresponde ahora ubicar a la cláusula penal en el marco de contratos cuya ejecución se ha visto afectada por las consecuencias de la pandemia actual.

Centraremos nuestra atención en los contratos de arrendamiento, que, como sabemos, se caracterizan por ser de tracto sucesivo siendo la contraprestación el pago de una renta (generalmente, en dinero). Este contrato, es quizás, uno de los que más se ha visto afectados en esta época ( $\sin$ mencionar a los contratos de construcción). El impacto económico de la crisis sanitaria ha afectado a casi el $30 \%$ de la población que habita en viviendas arrendadas (sean casas, departamentos u otros) $)^{(16)}$ en el departamento de Lima. Para nadie es un secreto que, como consecuencia de la paralización de actividades económicas, los arrendatarios: personas naturales y jurídicas, han dejado de cumplir con sus contraprestaciones. Esto ha provocado atrasos en el pago de las rentas de, por lo menos 4 o 5 meses; sin contar con las cláusulas penales exigibles y vigentes en los contratos. El panorama es desolador, muchos inquilinos de casas-habitación han sido expulsados y, por el lado de los

(15) Según la RAE, la palabra "irregular", significa, "que está fuera de regla, contrario a una regla, que no observa el mismo comportamiento o no rinde del mismo modo (...)". Y la palabra "defectuoso" significa "imperfecto, falto".

(16) Según el reporte del INEI, en 2018 , el $65,7 \%$ de los pobladores habitaban en viviendas propias, lo que significa, que alrededor, de un $30 \%$ ocupaban viviendas arrendadas. 
establecimientos comerciales, se observa un cierre masivo de todo tipo de negocios; en síntesis, una severa recesión económica (CCL, 2020) (Gestión, 2020) (INEI, 2020).

Esta situación despertó el interés de gran parte de la doctrina peruana, pero se focalizaron en el análisis de los efectos derivados del incumplimiento total y los remedios aplicables por el deudor. En este sentido, se ha analizado la liberación de responsabilidad del deudor por fuerza mayor (Ronquillo, 2020) (Rioja, 2020) (Varsi, Torres, \& Rosenvald, 2020), la posiblidad de aplicar la teoría de imprevisión y revisar el contrato por excesiva onerosidad de la prestación (Ninamancco, 2020) (Cieza, 2020) (Santos, 2020), la extinción del contrato aplicando la teoría de la frustración, etc.

Sin embargo, estas opiniones no han forjado un criterio unánime, pues el profesor Leysser León aporta argumentos contrarios. En relación a la postura de aquellos que ven la justificación del incumplimiento en la excesiva onerosidad de la prestación, el profesor León está en desacuerdo por considerar que el estado crisis sanitaria no ha alterado la relación inicial de valor entre prestación y contraprestación. "En los arrendamientos y pensiones no se ha alterado el valor, lo que han cambiado son las prestaciones mismas, que o no se ejecutan o no se pueden ejecutar regularmente" (León, 2020), debido a las decisiones gubernamentales y normas de urgencia que han tenido un fuerte impacto en las actividades económicas y el empleo. El mismo autor descarta también el argumento de la fuerza mayor como eximente de responsabilidad por incumplimiento.

Al respecto, señala que el pago de la renta al tener por objeto una prestación dineraria, se constituye en las denominadas "obligaciones genéricas", determinadas en su especie y cantidad. El género "dinero" no perece. Nadie puede invocar un caso fortuito o fuerza mayor como impedimento para honrar el pago de una deuda. No tener dinero o haberlo perdido por un robo o una mala inversión no son hechos que libren al deudor de sus obligaciones frente al acreedor" (León, 2020).

En Colombia, el problema de los arrendamientos, especialmente de los locales comerciales, reviste tal importancia que, en junio de 2020, el gobierno colombiano expidió el Decreto 797 facultando a los arrendatarios a ejercer un derecho de terminación unilateral y anticipada de ciertos contratos de arrendamiento. Dentro de los derechos reconocidos al arrendador se encuentra la negativa al ejercicio del derecho de resolución anticipada si el arrendatario no se encuentra al día con el pago de la renta, de los servicios públicos y demás gastos vinculados al inmueble. Asimismo, tiene derecho al cobro de un tercio $(1 / 3)$ de la penalidad establecida en el contrato, siendo que, de no haberse pactado una cláusula penal, tendrá derecho a recibir el equivalente a un (1) mes de renta.

Como vemos, en el Derecho colombiano el problema ha quedado zanjado, al menos para arrendamientos comerciales, por la propia norma. Resulta interesante cómo la intervención del Estado, justificada a través de una medida de emergencia, vulnera la autonomía de las partes, y la del contrato mismo, en un afán de proteger al deudor y salvaguardar la continuidad de los negocios. Se ha señalado que, "la norma busca un equilibrio de las cargas entre arrendador y arrendatario en la coyuntura actual. La idea es que las empresas puedan cubrir costos fijos, especialmente, los relacionados con la nómina de los trabajadores" (Mincomercio, 2020). El decreto colombiano se aplicaría principalmente a los locales comerciales que, debido a las medidas de aislamiento social, no puedan ejercer sus actividades económicas, como: gimnasios, discotecas, bares, piscinas, spa, saunas, cines, teatros, servicios religiosos, canchas deportivas, parques de atracciones, servicio alojamiento y restauración, etc.

Las micro, pequeñas y medianas empresas son las que se dedican, principalmente, a ese tipo de actividades, siendo que, el costo fijo de alquileres representa alrededor del $38 \%$ de los gastos mensuales (Mincomercio, 2020). De ahí, la importancia para el gobierno colombiano de emitir una norma de tal naturaleza.

En nuestro medio, no contamos con norma similar, por lo que, la solución a los eventuales problemas relacionados al arrendamiento recae, en primer lugar, en las partes, y de lo contrario, en los tribunales.

De las opiniones y estudios revisados, observamos que, la gran mayoría, se han centrado en el análisis del incumplimiento de la obligación principal, la protección al deudor, y las alternativas que podrían argüirse para liberar al deudor de responsabilidad por dicho incumplimiento ${ }^{(17)}$. No se ha opinado respecto

(17) Cabe señalar que los remedios contenidos en el Código Civil peruano (en los artículos 1150 y 1151) para los casos de incumplimiento absoluto y cumplimiento parcial, tardío o defectuoso de la prestación, reconocen una serie de acciones en favor del acreedor a fin de satisfacer su interés, sin establecer diferencias entre casa-habitación o local comercial. Esta situación ha provocado que, hoy en día, muchos establecimientos comerciales mantengan sus puertas cerradas por impagos acumulados durante los meses de cese de actividades. 
de la cláusula penal y su exigibilidad en el momento en que se produce el incumplimiento.

En el marco de un arrendamiento, sea de casa-habitación o de establecimiento comercial, de haberse pactado una cláusula penal compensatoria, el arrendatario incumplidor quedaría obligado al pago de la penalidad (artículo 1341, CC). Solamente, si dicha penalidad es manifiestamente excesiva, podrá el deudor, solicitar judicialmente la reducción. De lo contrario, no será posible. Ahora bien, respecto de la subsistencia de la cláusula penal compensatoria, quedará indefectiblemente atada a la "vida útil" de la obligación cuyo cumplimiento asegura. Es decir, si el deudor logra liberarse del cumplimiento de la obligación principal, en aplicación del adagio: "lo accesorio sigue la suerte de lo principal", quedará librado de la penalidad también.

Si la cláusula penal fuera de naturaleza moratoria, y el deudor cumple de manera parcial o defectuosa, la obligación principal, es decir el pago de la renta; entonces, el acreedor puede exigir el cumplimiento íntegro de dicha obligación, así como el pago de la penalidad. En esta situación, sí sería conveniente que el deudor solicitara la reducción judicial, pues la pena no cumple un fin sustitutorio sino más bien, cumulativo. En otros términos, el cumplimiento de la obligación principal de forma parcial o defectuosa, no inhibe el derecho del acreedor de exigir el pago de la penalidad. Nos preguntamos entonces, ¿qué pasaría si el deudor logra liberarse de la obligación principal, se libera también del cumplimiento de la penalidad?

El maestro León Barandiarán (citado por Osterling \& Castillo, 2014) señalaba que "la pena es expresiva de los daños y perjuicios por incumplimiento, y no puede haber lugar a éstos cuando el incumplimiento no es imputable al deudor, pues en tal hipótesis se resuelve la obligación principal (...) el principio mismo que informa la recíproca relación entre la pena y la obligación principal está constituido porque la extinción de la última acarrea la de la primera (...)" (Osterling \& Castillo, 2014, p. 2785).

Esto significa, entonces, que si el deudor logra demostrar que su incumplimiento no le es imputable (por ausencia de dolo o culpa), pudiendo liberarse de la obligación principal y de la cláusula penal, si el evento que desencadenó el incumplimiento responde a las características del caso fortuito o de fuerza mayor.

Para finalizar este acápite, consideramos necesario mencionar la propuesta de mejora del Anteproyecto de Reforma del Código Civil peruano, publicada en marzo de 2019. Según la propuesta, el artículo 1346 quedaría redactado de la siguiente manera: "El juez podrá, inclusive de oficio, previo contradictorio entre las partes, reducir equitativamente la pena cuando sea manifiestamente excesiva, o cuando la obligación principal hubiese sido en parte o irregularmente cumplida. Es nulo todo pacto en contrario, así como la renuncia anticipada a solicitar la reducción de la cláusula penal”.
En la exposición de motivos de esta norma, se justifica la modificación del vigente artículo 1346 en el reconocimiento del carácter punitivo de la cláusula penal. La intervención judicial de oficio constituye una novedad, pues de acuerdo a la norma vigente, dicha actuación debe ser solicitada por el deudor.

\section{Conclusión}

La cláusula penal es un mecanismo legal que cumple diferentes funciones en razón de la tipología adoptada por los contratantes. Si es del tipo compensatorio, entonces la función será sustitutoria de los daños y perjuicios; pero, si es moratoria, entonces, ésta será más bien sancionadora. La posibilidad de acumular la penalidad convenida más el cumplimiento de la obligación principal caracteriza a este tipo de cláusula. El debate en torno a su inmutabilidad o mutabilidad relativa parece haberse decantado por esto último; pues la mayoría de legislaciones admite la posibilidad de su revisión por parte del juez. Sobre este tema, la legislación española, específicamente, el Código Civil, utiliza términos imprecisos que han generado en la doctrina interpretaciones diversas respecto de la intervención judicial y su facultad de moderación de la pena. La "modificación equitativa de la pena" por parte del juez, ha sido interpretada como "reducción", aunque estricto, ése no sea el significado. No ocurre lo mismo con el BGB; el legislador alemán sí ha sido mucho más preciso al delimitar los supuestos de intervención del juez: reduce la pena cuando sea manifiestamente excesiva o cuando la obligación principal se hubiese cumplido en parte o de manera irregular.

La expresión "manifiestamente excesiva", utilizada también por nuestro código civil, plantea la cuestión relativa la forma de apreciar la desproporción de la cláusula penal. En ese sentido, según la Propuesta de Modernización del Código Civil español en materia de Obligaciones y Contratos, lo excesivo de la cláusula se mediría en función al daño efectivamente sufrido. Esta expresión es poco clara, habida cuenta, que la cláusula penal, como hemos señalado no cumple solamente una función sustitutoria de daños. 
En nuestro medio, es el juez quien aprecia según su saber y entendimiento, y determina si la cláusula es desproporcionada o manifiestamente excesiva. Ahora bien, también es posible solicitar la intervención del juez cuando la obligación principal ha sido cumplida parcial o defectuosamente.

La vigencia de la cláusula penal, en estos tiempos difíciles, se vuelve manifiesta cuando en los contratos de arrendamiento sancionan la mora en el cumplimiento del pago de la renta. En este supuesto, el acreedor puede exigir ambas cosas: el cumplimiento y la pena. El deudor no tiene muchas posibilidades de cumplir, habida cuenta, del impacto económico de las medidas adoptadas para contener la pandemia. En este contexto, el legislador colombiano en un afán de preservar a las micro, pequeñas y medianas empresas, arrendatarias de locales comerciales, y ayudar en el pago de sus trabajadores ha intervenido normando la reducción de las cláusulas penales vigentes. Si bien es una medida temporal, no deja de ser una irrupción y afectación al principio de libertad de contratación y de la autonomía de las partes.

El legislador peruano no se ha emitido ninguna norma de urgencia, en ese sentido; son pues, las normas del Código Civil las llamadas a resolver estos problemas. En vista del carácter accesorio de la cláusula penal, la única manera para el deudor, de liberarse de su cumplimiento es demostrar que la inejecución de sus obligaciones se debió a un caso fortuito o fuerza mayor.

\section{Referencias bibliográficas}

Acedo, J. (2011). Teoría General de las Obligaciones (2a . ed.). Dykinson. Albaladejo, M. (1997). Derecho Civil (10. ${ }^{a}$ ed., vol. 1, T. II.). Bosch.

Arana de la Fuente, I. (2009). La pena convencional y su modificación judicial. En especial, la cláusula penal moratoria. Anuario de Derecho Civil, 62(4).

Biquet-Mathieu, C. (2004). Les peines privées - Rapport de droit belge. Journées québécoises de l'Association Henri-Capitant.

Blanco, J. (1996). La cláusula penal en las obligaciones civiles: relación entre la prestación principal, la prestación principal y el resarcimiento del daño . Dykinson.

Cabanillas, A. (1991). Comentarios a los artículos 1152-1155 CC. En C. Paz-Ares (ed.), Comentario del Código Civil ( T. II). Ministerio de Justicia.

Cárdenas, C. (1994). Estudios de Derecho Privado I. Ediciones Jurídicas.

Carrasco, A. (2013). Artículo 1152. En R. Bercovitz, Comentarios al Código Civil (T. IV). Tirant lo Blanch.

CCL. (2020). La Cámara. Revista de la Cámara de Comercio de Lima. https://lacamara.pe/wp-content/uploads/2020/03/LA_CAMARA-922_ OK.pdf

Cieza, J. (2020). El Covid-19, el desequilibrio contractual y la excesiva onerosidad de la prestación. Gaceta Civil y Procesal Civil.
Contreras, J. (2012). La tasación de perjuicios mediante cláusula penal en el derecho colombiano. Revista de Derecho Privado.

De Castro, G. (2003). La cláusula penal. Utilización y acumulación de los remedios. Tutela preventiva y sumaria. Referencia al arbitraje. En J. de la Cuesta \& C. Vattier (eds.), Código Europeo de Contratos. Comentarios en homenaje al Prof. D. José Luis de los Mozos (vol. II). Dykinson.

Díez-Picazo L. (2008). Fundamentos del Derecho Civil Patrimonial (6. ${ }^{a}$ ed., T. II.). Civitas.

Espín, D. (1946). La cláusula penal en las obligaciones contractuales. Revista de Derecho Privado, 145-169.

Fuenteseca, C. (2011). Diversos matices de la regulación de la cláusula penal en el ordenamiento español y alemán. Foro, Nueva Epoca.

Gestión. (2020, 22 de junio). Más de la mitad de inquilinos en Lima rebajó el alquiler que paga. Gestión.

INEI. (2020). En Abril de 2020 la actividad económica disminuyó en $65.41 \%$. Instituto Nacional de Estadística e Informática. http://m.inei.gob.pe/ prensa/noticias/en-abril-de-2020-la-actividadcomercial-disminuyo-6541-12269/

Jalil, E. (2016). Comentarios a los artículos 790 a 803. En M. Herrera, G. Caramelo \& S. Picasso (eds.), Código Civil y Comercial de la Nación Comentado ( $2^{\mathrm{a}}$ ed., vol. 3 ). Infojus.

Kemelmajer de Carlucci, A. (1981). La cláusula penal. Depalma.

Lacruz, J. (2011). Elementos de Derecho Civil (5. ${ }^{\text {a }}$ ed., vol. 1, T. II). Dykinson.

Lano, P. (s.f.). Doc. parl., Ch. repr., sess. ord. 1997-1998, n 1373/4, Commission chargée des problèmes de droit commercial et économique.

León, L. (2020, 27 de abril). Covid-19, crisis sanitaria y retos del derecho civil: Entre la fuerza vinculante y la adecuación de los pactos contractuales. La Ley. https://laley.pe/art/9619/ covid-19-crisis-sanitaria-y-retos-del-derecho-civilentre-la-fuerza-vinculante-y-la-adecuacion-de-lospactos-contractuales

Lobato de Blas, J. (1974). La cláusula penal en Derecho español. EUNSA.

López, J. (1978). Obligaciones y contratos frente a la inflación. Editorial Jurídica de Chile.

Luna, A., Piñeiro, J., Ramos, S., \& Rubí i Puig, A. (2002). Reparación in natura y por equivalente: opciones de la víctima en el derecho español. Indret. 
Marín, I. (2017). La liquidación anticipada del daño. Análisis económico de la cláusula penal. Agencia Estatal Boletín Oficial del Estado.

Mincomercio. (2020). Abecé. Decreto 797 de 4 de junio de 2020. Mincit. http://colombiasigueadelante. mincit.gov.co/colombia_sigue_adelante/media/ archivos/pdf/JUN-5-JF-ABBC-DECRETOARRENDAMIENTOS-1_1.pdf

Moreau-Margreve, I. (2000). Variations sur un thème récurrent: la clause pénale. En P. Van Ommeslaghe (ed.), Mélanges offerts à P. Van Ommeslaghe. Bruylant.

Ninamancco, F. (2020). El Covid-19 y los contratos de arrendamiento. La Ley: https://laley.pe/art/9406/ el-covid-19-y-los-contratos-de-arrendamiento

Osterling, F., \& Castillo, M. (2008). Compendio de Derecho de las Obligaciones. Palestra.

Osterling, F., \& Castillo, M. (2014). Tratado de Derecho de las Obligaciones (2. ${ }^{a}$ ed., vol. 6). Thomson Reuters.

Pothier, R. (2007). Tratado de las Obligaciones $\left(2^{\circ}\right.$ ed.). (G. Torres, trad.). Heliasta.

Prado, A. (2019). Algunos aspectos de la Cláusula Penal en el Derecho Chileno. Revista de Derecho (Coquimbo).

Rioja, A. (2020). La inejecución del contrato de arrendamiento en tiempos de Covid-19.
La Ley. https://laley.pe/art/9567/la-inejecucion-del-contrato-dearrendamiento-en-tiempos-del-covid-19

Roca, R. \& Puig, J. (1948). La cláusula penal en las obligaciones contractuales (Tomo I.). Estudios de Derecho Privado.

Ronquillo, J. (2020, 21 de mayo). El impacto de la crisis sanitaria del Covid-19 en los contratos de arrendamiento. LP Pasión por el derecho. https://lpderecho.pe/crisis-sanitaria-covid-19-contratosarrendamiento/

Santos, P. (2020, 30 de abril). Covid-19 en el Perú y sus implicancias en distintos contratos civiles desde un enfoque de empresa. LP Pasión por el Derecho. https://lpderecho.pe/covid-19-implicancias-contratosciviles-empresa/

Sanz, A. (1994). La cláusula penal en el Código Civil. Bosch.

Soto, C. (2016). Cláusula penal: función e inmutabilidad de las penalidades libremente pactadas. En C. Soto (ed.), Incumplimiento Contractual. Jurivec-Flores Nano \& Soto.

Ternera, F. (2007). El concepto de justicia contractual. Revista Oficial del Poder Judicial, 1(2), 287-301.

Van Ommeslaghe, P. (1986). Les obligations - Examen de jurisprudence (1974-1982). R.C.J.B., (112), 1974-1982.

Varsi, E., Torres, M., \& Rosenvald, N. (2020). La pandemia de la covid-19, la fuerza mayor y la alteración de las circunstancias en materia contractual. Acta bioethica, 26(1), 29-36. https://dx.doi. org/10.4067/S1726-569X2020000100029

Wéry, P. (2001). Les clauses applicables en cas d'inexécution des obligations contractuelles. La Charte. 